\title{
CRIMINAL ACTIVITY THAT ENCROACHES ON THE INTEGRITY OF THE STATE BORDER OF UKRAINE
}

\section{Liudmyla Litvin}

\section{INTRODUCTION}

Since effective date of independence, Ukraine has faced new threats caused by the newly formed and existing in 1991 state borders. It is a threat to the territorial integrity and sovereignty of Ukraine, the terrorist threat, the growth of transnational and organized crime and illegal migration, smuggling of weapons, explosives and drugs, in the context of the present military conflict on the territory of the state.

An integral attribute and spatial basis of existence of the state is its territory, the boundaries of which are determined by the state border, and within which it has sovereignty and territorial supremacy. Today, this fundamental basis in relation to Ukraine as a state has been grossly violated by the Russian Federation, which inflicts aggressive actions with the aim of destroying our state and seizing its territory.

Therefore, the issue of protection and defense of the state border without exaggeration is more acute and urgent than ever and refers both to the state as a whole and to its individual institutions.

\section{Types of encroachments on the integrity of the state border}

In 1991, the State Border Guard Service of Ukraine detained 885 border violators, of which 148 were irregular migrants, then in 1994 were already detained 20529 border violators, of which 11444 irregular migrants (Kabahcynsky, 2006) ${ }^{1}$.

Since 1991, border guards revealed on the border of Ukraine about 330 thousand illegal migrants, some of whom were sent out from the country. From this number 123 thousand illegal migrants have been detained for illegal border crossing. Another 180,000 people, who were considered potential migrants, were denied entry.

${ }^{1}$ Kabahcynsky.I. (2006) Na varti rubezhiv Batkivshchyny: Prykordonni viyska Ukrainy v 1991-2003 rokah [Guarding the borders of the homeland: Border Guard Troops of Ukraine in 1991-2003]. Khmelnitsky: Publication of National Academy of State Border Guard Service of Ukraine, B. Khmelnitsky. 564 pp. (in Ukrainian) 
In 2017, the National Police of Ukraine (NPU), together with the Security Service of Ukraine (SSU) and the State Border Guard Service of Ukraine (SBGSU), terminated the activity of two organized criminal groups involved in illegal activity in the field of illegal migration, which were revealed in the Volyn and Kharkiv regions. Each of these groups consisted of three people. In 2017, law enforcement agencies identified 159 criminal offenses under article 332 of the Criminal Code of Ukraine (Illegal transportation of persons across the state border) (in 2016 - 154), 97 persons who were involved in this illegal activity were identified (56 in 2016). The state migration service of Ukraine (SMSU) identified 9,678 illegal migrants in 2017 (6,390 in 2016, that is the increase is $51.5 \%$ ). There were taken 9,264 decisions on forced return regarding the illegal migrants, of which 4,416 and 376 - on forced return, of which 214 were performed. The SBGSU in 2017 detected three thousand cases of irregular migration and 3.8 thousand people. In January 2018, the SBGS of Ukraine sent out 93 illegal migrants (2017-863 people). According to the SBGSU in 2017 compared to the previous year, the number of illegal migrants increased by $26 \%$ (Besida, 2018) ${ }^{2}$.

In 2018, 3270 illegal migrants were detained by the SBGSU. At the same time, the number of detainees for illegal border crossing increased by $26 \%$ and is 1130 people. Besides, if in 2017678 illegal migrants were detained at the EU border for illegal border crossing, in 2018 were detected 24\% more (842) of them. Mostly they tried to get to the EU countries across the border with Slovakia - 405 people and Poland 252 people, as well as with Hungary - 97 people and Romania - 88 people. Another significant part of the detained illegal migrants, and this is more than 2100 people, violated the rules of stay in Ukraine. Among them are the citizens of Moldova (1372), Russia (141), Bulgaria (97), Azerbaijan (70), Vietnam (52) and Turkey (50), who most often violated Ukrainian legislation. Besides, during border control at the border cross points, employees of the SBGSU found and denied entry to the territory of Ukraine almost 4650 potential illegal migrants.

The main ways of smuggling illegal migrants through the border crossing point are by using of valid passport documents along with invitations from fake individuals or non-existing enterprises, fake invitations from educational institutions, as well as foreign and fake

\footnotetext{
${ }^{2}$ Besida D. (2018) Mihratsiina kryza v YeS ta yii vplyv na bezpekovu sytuatsiiu v Ukraini [The migration crisis in the EU and its impact on the security situation in Ukraine]. Entrepreneurship, economy and law. no. 12. Pp. 299-303.
} 
passports, including European countries, permanent (temporary) residence permit in Ukraine, and during transit through Ukraine - the use of a double package of passport documents. At the same time, beyond the border crossing points the illegal migrants smuggling is performed by the organizers and usually in small groups (3-4 people) on their own, when migrants are «equipped» with mobile devices and GPS navigators, or accompanied by accomplices from among the local residents of the border areas or representatives of foreign diasporas.

At the same time, there is a tendency to increase the number of groups of illegal migrants to $10-20$ people. The general trends of threats of illegal migration in 2017 was characterized by a practical cessation of functioning of channels of transportation of illegal migrants from Afghanistan and decline of illegal migration of citizens of Georgia to Slovakia, Syria and Turkey to Hungary; the intensification of illegal migration to Slovakia by citizens of Vietnam, India, Syria, Turkey and the growth of the risks of smuggling of illegal migrants in Ukraine from Vietnam, Bangladesh and India beyond the border crossing points with Russia $(2017)^{3}$.

In January-June 2018, according to article 332 of the Criminal Code of Ukraine «Illegal transportation of persons across the state border of Ukraine»: 157 criminal violations were taken into account, persons were served a notice of suspicion for 52 criminal violations, and for 40 - sent to court with an indictment. Thus, the number of cases that reached the court as of June 2018, is $25.5 \%$ of the total number of criminal offenses for this period (of those that are included in the URPI).

In modern scientific works, as a rule, it is stated, that the subject of forensic science covers two groups of regularities - the mechanism of committing crimes and their reflection in the environment, as well as the regularities manifested in the activities of detection, disclosure, investigation of crimes and their prevention (Korzh, 2018) ${ }^{4}$.

Forensics are interested in crime not in general, not as a complex social phenomenon, but as illegal activity, as an act of human behavior, emphasizing that the object of criminology is the functional side of the crime, that is, criminology is interested only in part of the system

\footnotetext{
3 Mihratsiinyi profil Ukrainy za 2017 rik. [Migration profile of Ukraine for 2017]. Retrieved from: https://dmsu.gov.ua/diyalnist/monitoring-migraczijnix-proczesiv/ migraczijnij.html (accessed 14.06.2019).

${ }^{4}$ Korzh V. P. (2018) Deiaki dyskusini pytannia shchodo suchasnoho rozvytku nauky kryminalistyky. [Some debatable questions concerning modern development of forensic science]. Criminology and judicial examination. Vol. 63(1). Pp. 27-36.
} 
«criminal activity» - its display (prints, mental images), its mechanism, which is a system of interrelated elements, resulting in a «trace picture», which the investigator learns during the investigation of a specific crime (Averyanova, 2000) ${ }^{5}$.

M. V. Danshin points out that criminal activity, as a specific (negative) kind of human activity, in criminology is reflected in the form of the doctrine about the mechanism of committing a crime, as well as in the form of forensic characteristics of crimes of certain types in the methods of their investigation (Danshin, 2013). ${ }^{6}$ There is a point of view that criminology should study criminal activity much wider than understanding of the mechanism of the crime. Thus, N. S. Karpov identifies areas of forensic study of criminal activity, which relate to the organization of criminal communities, organization of the distribution of functional responsibilities of their members, «training», their counterintelligence activities to counter law enforcement agencies, etc. (Karpov, 2004) ${ }^{7}$.

V. P. Bakhin believes that criminal activity fully corresponds to the definition of activity as an active influence of a social subject on the object, which is carried out with the help of certain means (methods, techniques, tools) to achieve the goal set by the subject. Therefore, the fight against crime requires the study of criminal activity as a social phenomenon and a factor in the life of crime, and not only its individual components - criminal acts (Bakhin, 2002) ${ }^{8}$.

Criminal activity as an object of criminology, according to V.V. Tishchenko, represents beforehand planned system of actions of the person, and quite often organized group of persons for preparation, commission and concealment of a series of crimes for achievement of constant results and planned for rather long period of their activity (Tishchenko, 2006) ${ }^{9}$.

5 Averyanova T. V., Belkin R. S., Korukhov Yu. G., Rossinskaya E. R. (2000) Krymynalystyka [Forensic science]. Moscow: NORMA, 990 pp. (in Russian)

${ }^{6}$ Danshin M. V. (2013) Pro ob`iekt i predmet kryminalistyky ta yii zv`iazky z inshymy yurydychnymy naukamy [On the object and subject of criminology and its connection with other law sciences]. Collection of scientific works of Kharkiv national pedagogical University named after G. S. Skovoroda «LAW». Issue 20. Pp. 98-107.

${ }^{7}$ Karpov N. S. (2004) Zlochynna diialnist [Criminal activity]. K.: Semenko S. Publishing, 310 pp. (in Ukrainian)

${ }^{8}$ Bahin V. P. (2002) Krymynalystyka. Problemы y mnenyia (1962-2002). [Criminology. Problems and opinions (1962-2002)]. Kiev, 2002. 268 pp. (inRussian)

9 Tishchenko V. V. (2006) Zlochynna diialnist yak obiekt kryminalistyky. [Criminal activity as object of Criminology]. Actual problems of state and law. Vol. 27. Pp. 139-145. 
S. F. Denysyuk adheres to the point of view that criminal activity is a way of existence of a certain part of society, the procedure of its life support, and not only specific acts to achieve specific (individual) criminal goals. Therefore, it is necessary to study criminal activity as a social phenomenon, and it should be studied along with other types of human activity, taking into account all the main components, such as, the motive, purpose, means and ways of achieving this goal, the sequence of actions, the object, the subject of activity, the process of work, the result, without the limitations to the study of individual acts of criminal behavior. Like any activity, its criminal variety has a sequence of development, its inherent elements of professionalism and organization. If during the fight against crime do not take into account these aspects and study only individual crimes, and develop accordingly to them the means of counteraction, it is impossible to talk about an effective fight against modern crime. Only by recognizing the existence of a socially dangerous phenomenon of criminal activity, carefully studying it, observing its development, it is possible to develop effective ways of countering this phenomenon, that will correspond to reality (Denysiuk, 2011) ${ }^{10}$.

In the forensic aspect, as L. I. Arkusha marks that the essence of organized crime is such criminal activity that is carried out by criminal organizations and is characterized as a special kind of criminal trade of criminal organizations that have the structure, internal organization, management and external relations (including corrupt ones) appropriate to the set of criminal goals. The level of organization of criminal organizations, as well as the scope of their activities depend on the methods of committing crimes by members of these formations. The higher the level of community organization, the more sophisticated and effective these methods are (Arkusha, 2017) ${ }^{11}$.

The trend in the development of organized crime is it's globalization, which means, first of all, the globalization of criminal entrepreneurship that becomes part of the world economic system. This trend is the result of manifestations of the worldwide globalization of society, which is accompanied by serious criminal consequences that are associated with the increasing influence of organized crime and the abatement of the

${ }^{10}$ Denysiuk S. F. (2011) Zlochynna diialnist: poniattia, struktura ta kharakterystyka yii elementiv [Criminal activity: the concept, structure and characteristics of its elements]. Law and Security. No. 1. Pp. 135-140.

${ }^{11}$ Arkusha L.I. (2017) Poniattia ta rivni orhanizovanoi zlochynnoi diialnosti [The concept and levels of organized criminal activity] Actual problems of operational-search counteraction to organized crime: materials of the international scientific-practical Internet conference. (Odessa, April 28, 2017). Odessa. Pp. 11-12. 
capacity of national states to combat it: «transparency of borders» in the presence of obstacles to the activity of the police of one state on the territory of another facilitate the transition across Europe of the members of criminal gangs; the increase of migration leads to the creation in the European states of numerous criminal groups on national or ethnic basis, rather solid and closed to the control of law enforcement agencies, etc.

Yevdokimenko S.V. defines organized crime as a form of hierarchical construction of the criminal community, the scale of which affects the socio-economic structure of the state (Yevdokimenko, 2002) ${ }^{12}$.

Some authors among the characteristic features of organized crime highlight:

- total influence on the social situation that is beyond the influence of the individual crime committed;

- the possibility to evolve from a social organization to individual illegal actions, when the organization formed with «non-criminal» purpose begins to commit crimes under certain circumstances;

- actual immunity from «traditional» preventive activities, the need to use the institutions of the state to counter this phenomenon;

- the highest level of organization of criminal practices rooted in the sphere of political relations which simultaneously covers economic, professional and official criminality;

- internationality, that consists in inclusion in structure of such criminality representatives of different nationalities; it does not exclude existence in its structure also organizations formed on an ethnic sign;

- structuring, that is manifested in the presence of such organizations by having a complex structure of relationships associated with other social institutions, as well as a strict hierarchy;

- flexibility, that is, the ability to interact with various socio-political institutions, to penetrate the legal institutions of the state, economy and society;

- propensity to use force, threats and blackmail to solve problems that impede the implementation of criminal schemes;

- criminal innovation, which is the use of the latest technology to achieve mobility, increase profits and avoid liability;

- mobility, which is the ability to change location, move beyond national borders, use modern international logistics corridors and communications;

${ }^{12}$ Yevdokimenko, P. V. (2002) Zlochynna diialnist: sutnist ta kryminalistychni aspekty borotby z neiu [Criminal activity: essence and criminalistic aspects of struggle against it]. Kiev: Soviet school. $17 \mathrm{pp}$. 
- focus on establishing control over a certain area of illegal activity, which is achieved in a tough confrontation with competitors;

- the ability to adapt to changes in the situation, economic, political, legal and other conditions, the use of gaps in legislation and institutional system for the implementation of criminal schemes;

- expressed material, mercenary motives of illegal activity (Zharovska, 2013) ${ }^{13}$.

\section{Illegal migration as a type of organized crime that encroaches on the inviolability of the state border}

World processes in the era of globalization are significantly affected by such a complex socio-economic, legal and political phenomenon as migration - one of the most serious problems of our time, the flows of which have reached such proportions that the governments of different countries cannot ignore this phenomenon (Malynovska, 2018) ${ }^{14}$.

As evidenced by the analysis of scientific sources, despite certain differences, the concept of migration is defined as resettlement, the movement of population (individual or groups of people) within a country or from one country to another, which is aimed at the attainment of resources in new territories and is associated with a temporary or permanent change of residence (Gusarov, 2016) ${ }^{15}$.

Types of migration depend on the criteria of its classification, such as: by type - organized and unorganized; by degree of control - legal and illegal; by territorial features - internal and external; by temporary signs - irreversible, temporary, seasonal, nomadic; attitude to the host country - emigration, immigration, assimilated, transit (Mosiondz, 2005) ${ }^{16}$.

On a legal basis, migrants are divided into: legal (who cross international borders legally); semi-legal (those who arrive legally and change their status), illegal (this provides for crossing the border: beyond border crossing points; through border crossing points using fake (invalid) documents; through border crossing points with concealment in

13 Zharovska G. (2013) Transnatsionalna zlochynnist : dzherela, oznaky, struktura vzaiemozviazkiv [Transnational criminality: sources, features, structure of interrelations]. Scientific Bulletin of Chernivtsi University. Issue 660. Jurisprudence. Pp. 111-117.

${ }^{14}$ Malynovska O.A. (2018) Mihratsiina polityka: hlobalnyi kontekst ta ukrainski realii [Migration policy: global context and Ukrainian realities]. K.: NISD. 472 pp. (in Ukrainian)

${ }^{15}$ S. M. Gusarov, A. T. Kosyk, O. Yu. Salmanova (2016) Mihratsiine pravo Ukrainy [Migration law of Ukraine]. - Kharkiv: House of advertising. 296 pp. (in Ukrainian)

${ }_{16}$ Mosiondz S. O. (2005) Administratyvno-pravovi osnovy derzhavnoi mihratsiinoi polityky $\mathrm{v}$ Ukraini [Administrative and legal bases of the state migration policy in Ukraine]. K. : Master of the XXI century. 206 pp. (in Ukrainian) 
the design features of vehicles, in goods, using other ways to avoid border control).

Today, there is no single approach to the definition of «irregular (illegal) migration». We support the point of view of those scientists who believe that illegal migration is crossing the borders of a state for a purpose or in a manner that violates its legislation, including international law (Ognev, 2017) ${ }^{17}$.

Illegal migration as a kind of migration and transnational organized criminal activity was studied by the scientists of Ukrainian and other countries: P. Bahin, O.F. Bantyshev, O.I. Bastrykin, I.K.Vasylenko, A.V. Ishchenko, L.Y. Kapitanchuk, N.S. Karpov, N.I. Klimenko, V.S. Kuzmichev, O.V. Kuzmenko, Yu.I. Litvin, O.A. Malynovska, A.P. Mozol, S.O. Mosiondz, A.F. Mota, T.E. Ognev, V.I. Olefir, N.A. Orlovska, O.I. Onysko, I.B. Pohila, A.M. Prytula, Yu.I. Rymarenko, A.S. Sainchyn, L.D. Samygin, I.I. Serov, V.O. Sych, I.V. Ivakhnyuk, G.M. Lapshin, V.F. Kozlov., N.P. Frolkin, V.H. Yarmaki and others.( Mota, 2019; Bahin, 2013; Sainchin, 2008; Yarmaki, 2015) ${ }^{18,19,20,21}$.

According to scientific studies of illegal migration, it has now reached the level of threat to national and border security not only in Ukraine, but also in other countries $(2018)^{22}$.

17 Ognev T. E. (2017) Nezakonna mihratsiia: kryminalno-pravovi ta kryminolohichni aspekty [Irregular migration: criminal-legal and criminological aspects]. Kiev. -20 pp.

${ }^{18}$ Mota A. F. (2019) Teoriia i praktyka protydii nelehalnii mihratsii orhanamy Derzhavnoi prykordonnoi sluzhby Ukrainy: administratyvno - pravovyi aspekt. [Theory and practice of combating illegal migration by the State border service of Ukraine: administrative and legal aspect]. dis. doc. of legal sciences'.12.00.07 «administrative law and process; financial law; information law». Khmelnitsky . 519 pp.

${ }^{19}$ Bahin V. P. (2013) Vyiavlennia ta rozsliduvannia nelehalnoi mihratsii [Identification and investigation of illegal migration]: [monograph]. / V. P. Bahin, L. Yu. Kapitanchuk, Yu. I. Litvin. - Khmelnitsky: Publishing House of the National academy of state Border service of Ukraine named after B. Khmelnitsky. 164 pp. (in Ukrainian)

${ }^{20}$ Sainchin A. S. I. B. Pohila, A. M. Prytula (2008) Metodyka rozkryttia nezakonnoho perepravlennia osib cherez derzhavnyi kordon Ukrainy (kryminalistychni ta operatyvnorozshukovi aspekty) [Methods of disclosure of irregular transportation of persons across the state border of Ukraine (forensic and operational-search aspects)]. Odessa: Phoenix. 368 p.: 4 ill. (in Ukrainian)

${ }^{21}$ Yarmaki V. Ch. (2015) Henezys nelehalnoi mihratsii ta yii suspilna nebezpeka [Genesis of illegal migration and itspublic danger]. South ukrainian legal chronicles. No. 1. Pp. 118-122.

${ }^{22}$ Pro natsionalnu bezpeku Ukrainy. Zakon Ukrainy [On the national security of Ukraine. Law of Ukraine] No. 2469-VIII / / Data of Verkhovna Rada of Ukraine. - 2018. - No. 31. Article 241. 
Illegal migration has the same reasons as other migrations, but they are more global, tragic, conflict. Some authors define the following classification of the main causes of illegal migration, in particular:

- political: incompleteness of contractual and legal registration of the state border of Ukraine; potential possibility of intervention in internal affairs of Ukraine in border areas from other States; existence of separatist tendencies in separate border areas; absence of effective mechanisms of ensuring legality, the rule of law, fight against crime, especially it's organized forms and terrorism; political persecution, the conflict or war.

- economic: low level of earnings and life of society; contradictions between the existing manufacturing and the needs of the population; unresolved problems of resource, financial and technological dependence of the national economy from other countries; uncontrolled outflow of material and financial resources outside of Ukraine; plundering of national wealth on the state border of Ukraine and in the exclusive (marine) economic zone, intensification of smuggling activities, uncontrolled export of capital and strategically important raw materials and goods; cross-border accidents, catastrophes and natural disasters; the possibility of spreading epidemics (epizootics), dangerous diseases of people and animals from neighboring States.

- psychological: the subjective factor, which means that defects of consciousness are determined by the main component in the complex of causes and conditions of offenses, and sometimes are it's only cause.

- sociological: gender, age, career, level of education, nationality of the offender; time of year; prices for consumer goods; society itself, in which the offender grows; the heterogeneity and variability of the normative-value system of society; social inequality of society; social assessment of the actions that society defines as illegal; low standard of living and social security of large segments of the population, the presence in the border areas large number of citizens of working age, not employed in socially useful activities which are potential base of complicity in illegal activities on the border.

- legal: imperfect legal framework that governs the state border regime, not only internal but also external; legal nihilism of citizens traveling across the state border of Ukraine; uncontrolled migration processes in Ukraine; illegal arrival in Ukraine for business trips, training, tourism and further moving to Western Europe countries. 
- military: the potential possibility of encroachment on the state sovereignty of Ukraine and its territorial integrity; the accumulation near the borders of Ukraine of troops and weapons that violate the balance of forces that have developed; military-political instability and conflicts in neighboring countries; creation and functioning of irregular armed groups both in Ukraine and in neighboring states (Dzudza, 2001) ${ }^{23}$.

Illegal migration, as such, carries a political, economic, demographic, ethno-cultural and, most importantly, criminal threat to the security of the Ukrainian state.

The complex «industry» of irregular migration is interlinked with human trafficking, drug trafficking and other transnational organized criminal activities.

The problem of irregular migration remains relevant, as it affects the security of the state, its international relations and can aggravate in the conditions of the Operation of the joint forces, the lack of control over a significant portion of the eastern border. Over the past decade, irregular migration of foreigners to / from and through Ukraine has become part of the overall migration process. Until 2015 , there was a tendency to a constant decrease in the number of illegal migrants that were detained at the border and detected in the state, and since 2015 - to an increase in the number of illegal migrants detected inside the state and at its borders $(2017)^{24}$.

The threat of terrorism forces governments to revise migration laws, to pay more attention to border protection, inevitably predetermines the strengthening of control, leads to a more picky, and even suspicious attitude to foreigners as carriers of certain threats. This trend was especially intensified after the terrorist attack on the United States in September 2001, and was further developed as a result of violent terrorist attacks in France, Belgium, the United Kingdom. Most immigrants are not terrorists, but most terrorists are immigrants. The researchers analyzed the files of 212 terrorists detained or killed in the United States and Western Europe in 1993-2003, 86 \% of whom were immigrants or citizens of immigrant origin. However, there is no reason to talk about a

23 Dzudza O. M. (2001) Kryminolohiia. Spetsializovanyi kurs lektsii zi skhemamy. (Zahalna ta osoblyva chastyny) [Criminology. Specialized course of lectures with diagrams. (General and special parts). K.: Atika. 366 p. (in Ukrainian)

${ }^{24}$ Stratehiia derzhavnoi mihratsiinoi polityky Ukrainy na period do 2025 roku. [Strategy of the state migration policy for the period up to 2025]. Approved by the order of the Cabinet of Ministers of Ukraine dated July 12, 2017 No. 482-R. //https://zakon.rada.gov.ua/laws/show/ $482-2017-\%$ D1\%80 
causal link between migration and terrorism. The only common thing between them is that in the context of globalization both of these phenomena are transnational in nature. Terrorists can live in one country, raise funds in another, and commit criminal acts in a third. Moreover, terrorism is not a product of migration. According to the global database of terrorist acts, from 1970 to 2015, 20,975 terrorist attacks were carried out in European countries, most of which were motivated by the struggle for recognition or independence of certain European radical groups. Only $2 \%$ of terrorist attacks were Islamic in nature (Malynovska, 2019) ${ }^{25}$. According to Frontex, 1.82 million migrants arrived in Europe in 2015, most of them are Muslims.

According to Western European experts, for all the chaotic movements of single migrants or small groups, irregular migration is a global phenomenon, which has its own complex structures and a high level of commercialization. In some cases, organizations that smuggle people may be comparable to large multinational corporations. Some authors indicate the availability of information on the involvement of the special services of Central Asian States in illegal migration and related crimes (Fedulov, 2004) ${ }^{26}$.

Today there is a phenomenon of «irregular migration in the international student exchange», which consists of two interrelated processes - illegal and criminal types. Thus, the flows of migrants, in order to realize their illegal intentions, plan to use the educational industry of Ukraine, caused mainly by the peculiarities of economic development, which, in particular, expand the possibilities of criminal business. Criminal migration in the international student exchange of Ukraine is considered as a kind of international voluntary migration with the use of invitations to study in educational institutions, due to factors of a criminal nature, and is defined as a set of movements of citizens of one state, that settling permanently or for a long time on the territory of our state for the purpose of criminal activity, as well as this activity itself and its consequences. The main type of crimes in the sphere of international

${ }^{25}$ Malynovska O. A. (2018) Mihratsiina polityka: hlobalnyi kontekst ta ukrainski realii [Migration policy: global context and Ukrainian realities]. K.: NISS. 472 p. (in Ukrainian)

26 Fedulov A.V., Terekhin V.V. (2004) Problemы rassledovanyia prestuplenyi, sovershennukh myhrantamy [Problems of investigation of crimes committed by migrants] // Migration, human rights and economic security of modern Russia: state, problems, effectiveness of protection: SB. art. / ed. V. M. Baranova. N. Novgorod. Pp. 452-457. 
student exchange is illegal migration in the form of illegal transportation of persons across the state border of Ukraine (Chernyak, 2017) ${ }^{27}$.

The phenomenon of illegal migration, characterized by the fact that migrants leave the country of their permanent residence and cross the borders of another state without official permission or violate the terms of stay established by the legislation of this country on its territory, is dangerous for any state, including Ukraine. Usually Ukraine acts in two roles: the final destination for immigrants mainly from the CIS countries; transit territory on the way to the European Union, mainly for immigrants from Asia and Africa.

Recently, a new threatening trend has emerged in the sphere of illegal migration. Due to the strengthening of measures to combat illegal migration in the European Union, there has been an increase in the number of migrants who are trying at any cost to get to Ukraine to stay here, to be able later to illegally enter the territory of the member states of the European Union.

The analysis of illegal migration gives grounds for the conclusion that it is a kind of transnational organized criminal activity. At the same time, it has such features as illegality, organization, scientific and information support, conspiracy, specialization, improvement, economy, scale, professionalism, transnationality and high technical armament.

The peculiarity of professional crime is that it «nurtures» in its environment a new kind of crime - organized crime, the activation of which often depends on the crisis phenomena in the state. Organized crime does not separate from the professional crime, and also takes it under its control, uses it as a branch of the shadow economy, from which it receives «income tax» (Kalganova, 2014) ${ }^{28}$.

In his scientific research Kremenchutsky S.M. draws attention to the fact that in Ukraine the activity of organized criminal groups, which specialize on creating highly efficient transnational system of management of illegal migration flows, the increasing of the flow of uncontrolled illegal immigration has led to a significant increase in the

${ }^{27}$ Chernyak A.M. (2017) Poniattia ta klasyfikatsiia zlochyniv u sferi mizhnarodnoho studentskoho obminu [The concept and classification of crimes in the field of international student exchange] / Scientific Bulletin of Uzhgorod national University, 2017. Vol. 46. Volume 2. Pp. 133-136.

${ }^{28}$ Kalganova O.A. (2014) Profesiina zlochynnist u II polovyni XX stolittia [Professional crime in the second half of the XX century]. Scientific Bulletin of Kherson state University. «Legal Sciences» Series. Issue 1 Volume 3 Pp. 42-45 
criminalization of society in the border regions of Ukraine (Kremenchutsky, 2010). ${ }^{29}$

Evidence of this is the functioning of established sustainable channels of illegal migration. It is the system created by groups of persons that provides illegal entry into Ukraine, stay and departure from its territory of migrants, and also - set of forces and means which are necessary for search of wishing to migrate illegally to the recipient countries, formation of groups, equipment with the corresponding documents, support on a route, temporary accommodation and accommodation in transit points.

The activities of such organizations are characterized by flexibility, which depends on the nationality of migrants, their ability to pay, the capacity of the organizers, the mode of transportation and other factors, and the channels of illegal smuggling of migrants often coincide with the channels of drug trafficking and illegal arms trade.

According to Interpol, 90 percent of people arriving in Europe get there through the system of illegal transportation, consists of a variety of loosely connected criminal groups. Criminals from more than a hundred countries are suspected of this activity. Interpol experts conclude that transport routes are changing rapidly under the influence of external conditions, such as strengthening border control. The illegal structure includes both criminal authorities, weakly controlling the entire route, and petty criminals, who organize transportation at the local level through personal connections. Illegal carriers of migrants earned in 2015 from 5 to 6 billion dollars (4.4-5.3 billion euros) It is one of the most important sources of income for organized crime in Europe $\left(\right.$ Delfinov, 2016) ${ }^{30}$

In $80 \%$ of cases, irregular migration through the territory of Ukraine is not spontaneous, but on the contrary, it is a well-organized and wellestablished business over the years.

Among the personnel of border units, which carried out tasks of operational and service activities $79.9 \%$ of respondents believe that illegal immigration is tied to illegal human transition across the border,

${ }^{29}$ Kremenchutsky S. M. (2010) Diialnist pravookhoronnykh orhaniv Ukrainy shchodo administratyvno-pravovoi protydii nelehalnii immihratsii [Activity of law enforcement agencies of Ukraine concerning administrative and legal counteraction to illegal immigration]. Lviv. 2010. $20 \mathrm{p}$.

${ }^{30}$ Delfinov A. (2016) Interpol: Nelehalnye perevozchyky myhrantov zarabotaly myllyardы evro [Interpol: Illegal migrant carriers have earned billions of euros]. Deutsche Welle. URL: http://www.dw.com/ru/ a-19264332/17.05.2016/02.10.2019 
67.9 percent - forgery of documents and use of them, $41.6 \%$ - human trafficking. Officers of operational-search units (93.6\%) answered about the dominant phenomenon of illegal migration with the transfer of humans across the border. Among the national diasporas that exist on the territory of Ukraine and contribute to illegal migration, $17.1 \%$ of servicemen (employees) with practical experience named Syrian, $14.3 \%$ - Afghan, 7.2\% - Vietnamese, 3.8\% - Somali and Turkish, $2.7 \%$ - Azerbaijani, Armenian, Georgian, Indian and Uzbek (Mota, 2019). ${ }^{31}$

The study of illegal migration shows that it covers not only migrants themselves, but also a structured global criminal network of a transnational nature, which includes criminal groups operating in several countries with sufficient technical support, while improving the forms and methods of criminal activity, which are becoming more sophisticated and improved, and accrue tens and even hundreds professionally trained and well-equipped members.

Monitoring of the ways of origin of illegal migrants indicates that $5.7 \%$ of offenders who entered the territory of the state illegally, it is mainly immigrants from foreign countries (Pakistan, India, China, Bangladesh, Sri Lanka, etc.); $94.3 \%$ of illegal immigrants (of the total number of detainees) entered Ukraine legally, but after the prescribed period of stay moved to an illegal situation; about $60 \%$ of illegal immigrants enter Ukraine through the border areas under formation - a border zone with Russia, Belarus and Moldova. The functioning of channels of illegal migration through Ukraine is also facilitated by the unsettled borders according to European parameters, the lack of control over part of the border in the East of Ukraine, corruption in our country, which allows migrants to cross the border and enter the EU.

The results of the activities of the SBGU in recent years indicate that the number of illegal migrant, following through the territory of Ukraine, is constantly growing, and the number of detained illegal migrants only in the areas of responsibility of the border protection bodies of the southern regional administration of the SBGU has increased 3-5 times. The analysis of detention of irregular migrants, filtration and verification measures testifies to existence of the fulfilled channels of illegal transit

\footnotetext{
${ }^{31}$ Mota A. F. (2019) Teoriia i praktyka protydii nelehalnii mihratsii orhanamy Derzhavnoi prykordonnoi sluzhby Ukrainy: administratyvno - pravovyi aspekt [Theory and practice of combating illegal migration by the State border service of Ukraine: administrative and legal aspect]. Khmelnitsky. 519 pp. (in Ukrainian)
} 
migration through the territory of Ukraine, also with use of forged documents.

The peculiarity of the functioning of channels of illegal migration is that illegal migrants from countries of origin to countries of destination are transported in stages through accumulation centers - hotbeds of criminal groups, as well as an increase in the migration flow of women (up to $58.5 \%$ ) and children (Sysiuk, 2014). ${ }^{32}$

Today, the territory of Ukraine is a place of "temporary stay» for foreigners, which means that foreigners arrive in Ukraine for a certain period of time for the purpose of tourism, training, employment, as a rule, remain illegally in Ukraine for 10 months or more, and after that illegally cross the western borders of the country in order to leave for permanent residence and employment in the EU countries.

\section{CONCLUSIONS}

However, due to significant changes in the migration policy of Western European countries, which are trying to stop the flow of illegal migrants, Ukraine is gradually turning from a transit country to a country of accumulation of illegal migrants. This is also facilitated by international agreements signed by Ukraine with the EU, according to which illegal migrants who arrived in transit through the territory of Ukraine in the order of readmission can be returned to Ukraine (2008). ${ }^{33}$

Ukraine is and, in the available for forecasting future, will remain a zone of criminal interests of organized crime. There will be a diversification of criminal activity, growth of its criminal professionalization. The strengthening of political, economic and humanitarian ties between our country and the European Union as a whole, as well as the member states adjacent to our state, will be used by organized crime to carry out cross-border crimes.

Occupying a significant place in the structure of migration flows, illegal migration is a socially dangerous, harmful, unlawful phenomenon that really threatens the national and border security of Ukraine.

${ }^{32}$ Sysiuk L. P. Giluk L. O.. (2014) Problemy nelehalnoi mihratsii v Ukraini ta v sviti [Problems of illegal migration in Ukraine and in the world] $X$ International Scientific-Practical Conference «Strategic Questions of World Science, 2014». (Przmysl, 07-15 february 2014). Przmysl. Pp. 78-82.

33 Pro ratyfikatsiiu Uhody mizh Ukrainoiu ta Yevropeiskym Spivtovarystvom pro readmisiiu osib :[On ratification of the Agreement between Ukraine and the European Community on the readmission of persons]: Law of Ukraine of 15 Jan. 2008 No. 116-VI// Data of the Verkhovna Rada of Ukraine. 2008. No. 9. St. 86. 
The analysis of migration processes and the causes of their occurrence gives grounds to assert that the overall level of migration processes, including illegal ones, will grow and that the world economic cataclysms will also significantly affect the increase and complication of the military confrontation in the Middle East.

\section{SUMMARY}

The article deals with the issue of illegal migration as one of the main threats to Ukraine's national security at the border area. The statistics on offenses at the state border was presented. The tactics of actions of offenders of border legislation are revealed.

In the article the author presented the results of the analysis of scientific researches which were conducted in the forensic sphere of scientific researches. The subject and subject of forensic science and its relation with other legal sciences are disclosed. It was determined the main types, causes, dynamic changes of organized criminality which implements illegal migration making a focus on its globalization, new threats to the world economic system, including the national security of Ukraine.

The author emphasizes that due to the intensification of counteract measures illegal migration in the European Union countries, the number of migrants entering Ukraine as a transit country, for father illegal entry the territory of the Member States of the European Union was increased.

\section{REFERENCES}

1. Kabahcynsky.I. (2006) Na varti rubezhiv Batkivshchyny: Prykordonni viyska Ukrainy v 1991-2003 rokah [Guarding the borders of the homeland: Border Guard Troops of Ukraine in 1991-2003]. Khmelnitsky: Publication of National Academy of State Border Guard Service of Ukraine, B. Khmelnitsky. 564 pp. (in Ukrainian)

2. Besida D. (2018) Mihratsiina kryza v YeS ta yii vplyv na bezpekovu sytuatsiiu v Ukraini [The migration crisis in the EU and its impact on the security situation in Ukraine]. Entrepreneurship, economy and law. no. 12. Pp. 299-303.

3. Mihratsiinyi profil Ukrainy za 2017 rik. [Migration profile of Ukraine for 2017]. Retrieved from: https://dmsu.gov.ua/diyalnist/ monitoring-migraczijnix-proczesiv/migraczijnij.html 14.06.2019).

4. Korzh V. P. (2018) Deiaki dyskusiini pytannia shchodo suchasnoho rozvytku nauky kryminalistyky. [Some debatable questions 
concerning modern development of forensic science]. Criminology and judicial examination. Vol. 63(1). Pp. 27-36.

5. Averyanova T. V., Belkin R. S., Korukhov Yu. G., Rossinskaya E. R. (2000) Krymynalystyka [Forensic science]. Moscow: NORMA, 990 pp. (in Russian)

6. Danshin M. V. (2013) Pro ob iekt i predmet kryminalistyky ta yii zv 'iazky z inshymy yurydychnymy naukamy [On the object and subject of criminology and its connection with other law sciences]. Collection of scientific works of Kharkiv national pedagogical University named after G. S. Skovoroda «LAW». Issue 20. Pp. 98-107.

7. Karpov N. S. (2004) Zlochynna diialnist [Criminal activity]. K.: Semenko S. Publishing, 310 pp. (in Ukrainian)

8. Bahin V. P. (2002) Krymynalystyka. Problemы y mnenyia (19622002). [Criminology. Problems and opinions (1962-2002)]. Kiev, 2002. 268 pp. (inRussian)

9. Tishchenko V. V. (2006) Zlochynna diialnist yak obiekt kryminalistyky. [Criminal activity as object of Criminology]. Actual problems of state and law. Vol. 27. Pp. 139-145.

10. Denysiuk S. F. (2011) Zlochynna diialnist: poniattia, struktura ta kharakterystyka yii elementiv [Criminal activity: the concept, structure and characteristics of its elements]. Law and Security. No. 1. Pp. 135140.

11. Arkusha L.I. (2017) Poniattia ta rivni orhanizovanoi zlochynnoi diialnosti [The concept and levels of organized criminal activity] Actual problems of operational-search counteraction to organized crime: materials of the international scientific-practical Internet conference. (Odessa, April 28, 2017). Odessa. Pp. 11-12.

12. Yevdokimenko, P. V. (2002) Zlochynna diialnist: sutnist ta kryminalistychni aspekty borotby $\mathrm{z}$ neiu [Criminal activity: essence and criminalistic aspects of struggle against it]. Kiev: Soviet school. 17 pp.

13.Zharovska G. (2013) Transnatsionalna zlochynnist : dzherela, oznaky, struktura vzaiemozviazkiv [Transnational criminality: sources, features, structure of interrelations]. Scientific Bulletin of Chernivtsi University. Issue 660. Jurisprudence. Pp. 111-117.

14. Malynovska O.A. (2018) Mihratsiina polityka: hlobalnyi kontekst ta ukrainski realii [Migration policy: global context and Ukrainian realities]. K.: NISD. 472 pp. (in Ukrainian)

15. Gusarov S. M., Kosyk A. T., Salmanova O. Yu. (2016) Mihratsiine pravo Ukrainy [Migration law of Ukraine]. Kharkiv: House of advertising. 296 pp. (in Ukrainian) 
16. Mosiondz S. O. (2005) Administratyvno-pravovi osnovy derzhavnoi mihratsiinoi polityky $\mathrm{v}$ Ukraini [Administrative and legal bases of the state migration policy in Ukraine]. K. : Master of the XXI century. 206 pp. (in Ukrainian)

17.Ognev T. E. (2017) Nezakonna mihratsiia: kryminalno-pravovi ta kryminolohichni aspekty [Irregular migration: criminal-legal and criminological aspects]. Kiev. 20 pp.

18. Mota A. F. (2019) Teoriia i praktyka protydii nelehalnii mihratsii orhanamy Derzhavnoi prykordonnoi sluzhby Ukrainy: administratyvno pravovyi aspekt. [Theory and practice of combating illegal migration by the State border service of Ukraine: administrative and legal aspect]. Khmelnitsky . 519 pp. (in Ukrainian)

19. Bahin V. P., Kapitanchuk L. Yu., Litvin Yu. I. (2013) Vyiavlennia ta rozsliduvannia nelehalnoi mihratsii [Identification and investigation of illegal migration]. Khmelnitsky: Publishing House of the National academy of state Border service of Ukraine named after B. Khmelnitsky. 164 pp. (in Ukrainian)

20.Sainchin A. S., Pohila I. B., Prytula A. M. (2008) Metodyka rozkryttia nezakonnoho perepravlennia osib cherez derzhavnyi kordon Ukrainy (kryminalistychni ta operatyvno-rozshukovi aspekty) [Methods of disclosure of irregular transportation of persons across the state border of Ukraine (forensic and operational-search aspects)]. Odessa: Phoenix. 368 p.: 4 ill. (in Ukrainian)

21. Yarmaki V. Ch. (2015) Henezys nelehalnoi mihratsii ta yii suspilna nebezpeka [Genesis of illegal migration and itspublic danger]. South ukrainian legal chronicles. No. 1. Pp. 118-122.

22. Pro natsionalnu bezpeku Ukrainy. Zakon Ukrainy [On the national security of Ukraine. Law of Ukraine] No. 2469-VIII. Data of Verkhovna Rada of Ukraine. - 2018. - No. 31. Article 241.

23.Dzudza O. M. (2001) Kryminolohiia. Spetsializovanyi kurs lektsii zi skhemamy. (Zahalna ta osoblyva chastyny) [Criminology. Specialized course of lectures with diagrams. (General and special parts). K.: Atika. 366 p. (in Ukrainian)

24. Stratehiia derzhavnoi mihratsiinoi polityky Ukrainy na period do 2025 roku. [Strategy of the state migration policy for the period up to 2025]. Approved by the order of the Cabinet of Ministers of Ukraine dated July 12, 2017 No. 482- Retrieved from: // https://zakon.rada.gov.ua/laws/show/482-2017-\%D1\%80

25.Fedulov A.V., Terekhin V.V. (2004) Problemы rassledovanyia prestuplenyi, sovershennыkh myhrantamy [Problems of investigation of crimes committed by migrants]. Migration, human rights and economic 
security of modern Russia: state, problems, effectiveness of protection: SB. art. / ed. V. M. Baranova. N. Novgorod. Pp. 452-457.

26. Chernyak A. M. (2017) Poniattia ta klasyfikatsiia zlochyniv u sferi mizhnarodnoho studentskoho obminu [The concept and classification of crimes in the field of international student exchange]. Scientific Bulletin of Uzhgorod national University, 2017. No. 46. Vol. 2. Pp. 133-136.

27. Kalganova O. A. (2014) Profesiina zlochynnist u II polovyni XX stolittia [Professional crime in the second half of the XX century]. Scientific Bulletin of Kherson state University. «Legal Sciences» Series. Issue 1 Vol. 3. Pp. 42-45.

28. Kremenchutsky S. M. (2010) Diialnist pravookhoronnykh orhaniv Ukrainy shchodo administratyvno-pravovoi protydii nelehalnii immihratsii [Activity of law enforcement agencies of Ukraine concerning administrative and legal counteraction to illegal immigration]. Lviv. 2010. 20 pp.

29. Delfinov A. (2016) Interpol: Nelehalnye perevozchyky myhrantov zarabotaly myllyardy evro [Interpol: Illegal migrant carriers have earned billions of euros]. Deutsche Welle. Retrieved from: http://www.dw.com/ru/ a-19264332/17.05.2016/02.10.2019.

30. Sysiuk L. P. Giluk L. O.. (2014) Problemy nelehalnoi mihratsii v Ukraini ta $\mathrm{v}$ sviti [Problems of illegal migration in Ukraine and in the world] $X$ International Scientific-Practical Conference "Strategic Questions of World Science, 2014». (Przmysl, 07-15 february 2014). Przmysl. Pp. 78-82.

31.Pro ratyfikatsiiu Uhody mizh Ukrainoiu ta Yevropeiskym Spivtovarystvom pro readmisiiu osib :[On ratification of the Agreement between Ukraine and the European Community on the readmission of persons]: Law of Ukraine of 15 Jan. 2008 No. 116-VI // Data of the Verkhovna Rada of Ukraine. 2008. No. 9. St. 86.

\section{Information about the author:} Liudmyla Litvin,

$\mathrm{PhD}$ in Law, Associate Professor

Professor of the Department of Theory and History of State and Law and Private Law National Academy of State Border Guard Service of Ukraine named after B. Khmelnytskyi Schevchenko str. 46, Khmelnytskyi ORCID.ORG/0000-0003-2318-7085 